\title{
DEVELOPING A LEAN CULTURE INDEX IN CONSTRUCTION
}

\author{
Jessica Kallassy ${ }^{1}$ and Farook Hamzeh ${ }^{2}$
}

\begin{abstract}
Metrics and indices have become commonly available for construction planners in general, and Lean practitioners in particular, to evaluate and control their projects' performance. Amidst the ample availability of such measures, the fight against specious Lean implementation in different construction firms has been the concern of many researchers. In order to address this issue, and in an attempt to provide practitioners with new methods to assess the Lean culture, this research develops a Lean Culture Index that can be used to measure Lean culture and the readiness of an organization to apply Lean. It presents a comprehensive model to assess Lean culture, and it can be used as a basis for future models of Lean implementation. It also provides practitioners with a diagnostic tool that measures where areas need further improvement. The paper utilizes a thorough literature review to identify features of Lean culture. Then, a survey is conducted to assess the derived features. Analysis of the data revealed that although surveyed construction companies showed some relation to Lean culture such as flexibility and consistency, there is still room for improvement in areas such as training and human focus. The study is capped with recommendations and conclusions.
\end{abstract}

\section{KEYWORDS}

Lean construction index, lean culture, organizational culture.

\section{INTRODUCTION}

In a rapidly changing world, predicting upcoming changes is an impossible feat, and researchers believe that the velocity of change will continue to increase exponentially (Cameron 2003). For example, only sixteen out of one hundred large firms listed on Fortune magazine have survived since the early 1900s, which highlights the necessity for companies to update their systems in order to maintain their competency (Cameron and Quinn 2005). Although several companies are introducing new management concepts, most of them fail in implementing them due to their internal culture (Kotter 1996, Wandahl 2014). Therefore, it is important to understand the organizational culture within these companies and reshape them accordingly to embrace implement new systems successfully.

Several companies choose to adopt Lean construction (LC) as a new management concept within their companies. The major benefits of LC according to practitioners are reductions in construction time and overall project cost, increase in productivity,

1 Masters Graduate, Civil and Environmental Engineering Department, American University of Beirut, Beirut Riad El-Solh 1107 2020, Lebanon, jfk06@aub.edu.lb

2 Associate Professor, Department of Civil and Environmental Engineering, University of Alberta, Edmonton, Alberta, Canada, hamzeh@ualberta.ca, orcid.org/0000-0002-3986-9534 
improvement in product quality, and increase in customer satisfaction (Bernstein and Jones 2013, Hamzeh et al. 2016). Despite the mentioned benefits of LC implementation, several companies have failed in implementing LC due to the LC concepts being applied in a superficial manner by the company, or the concepts being inconsistent or conflicting with the existing organizational principles. That is why these attempts end up by being just a short-lived fad (Simonsen et al. 2014).

Ettore (1997) illustrated the five life cycle stages of new management concepts. The first phase is the discovery of the new management concept where people become aware of it from publications, advertisement, or other companies. In the second phase, these new management concepts gain momentum and are discussed more frequently among the enterprise. In the third phase, the concepts are further studied, analyzed, and criticized. Accordingly, the number of people interested in these concepts begins to decrease in phase four until only a small group keeps on supporting them towards the fifth phase. The lifecycle of a new management concept varies depending on its popularity and the readiness of the company to implement new management systems (Simonsen et al. 2014). Although companies usually focus on attaining results within a short time period, Emiliani (1998) stated that for an organization to properly achieve Lean behavior, it needs at least five to ten years of continuous work and commitment. Moreover, managerial boards and teams tend to rush the implementation of LC concepts without performing the required cultural changes nor embracing the lean philosophy (Shook 2010).

The goal of this research is to understand Lean culture as the primary step to its successful implementation. Accordingly, a Lean Culture Index (LCI) is developed to reflect the construction firms' Lean culture level. This index is then applied to medium and large-scale construction firms to help in assessing their existing culture and compare it to the Lean culture. After culture assessment, recommendations related to cultural change are given as a foundation for successful lean implementation.

\section{LITERATURE REVIEW}

\section{Organizational Culture}

The culture of an organization comprises many facets reflected through the adopted leadership style, work procedures, communication languages, and corporate logos and slogans. Additionally, the shared beliefs, values, and assumptions held by members of an organization define its culture, and they are usually the result of unwritten and unspoken rules shared among employees. This common culture is best manifested through people's behavior over the years. When a behavior is rewarded, employees usually repeat it and make it part of the organizational culture (Cameron \&Quinn 2005). Schein (2010) divides the organizational culture into three levels. At the surface level are the artifacts, which include all the visible elements that can be seen, heard, and felt. Beneath artifacts lies the second level comprising the firm's espoused beliefs and values. They are the beliefs upon which the company is built and are then developed into its code of conduct. The third level includes the basic underlying assumptions which are the foundations on which a company's culture is based. These assumptions consist of unconscious thoughts, beliefs, perceptions, and feelings; in other words, they reflect the way through which "things are done around here". Because these basic assumptions are neither discussed nor written and are difficult to pinpoint, changing them is extremely difficult.

Several studies have reported that the main reason behind failure when applying changes to an organization or introducing new management systems is the neglect of the 
organization's culture. The most common organizational changes applied are Total Quality Management (TQM) initiatives, downsizing initiatives, and reengineering initiatives (Cameron 1997). TQM was developed to increase effectiveness by delivering a higher quality product, yet several studies have shown that most firms did not successfully implement this initiative. On the other hand, some companies opt for downsizing initiatives to improve productivity, efficiency, competitiveness, and effectiveness. However, results have shown that the trust, morale, and productivity of personnel suffered after implementing this initiative (Cameron 1997). The same outcomes were observed for the application of reengineering design. Cameron (1997) concludes that the failure of those three initiatives is related to them having the same organizational culture where they focus on applying mere techniques rather than on changing their organization values, direction, goals, and culture.

The reason why organizational culture has been ignored throughout the years is that people remain bound to the definition, underlying assumptions, and unwritten guidelines of a company (Cameron \& Quinn 2005). In fact, people usually do not like change; they prefer to stick to their old habits, doing the same thing every day (Zammuto \& Krackower 1991). In other words, having the same organizational culture provides stability to employees and implementing any change is faced with rejection and fear.

\section{Different Types of Organizational Culture}

Organizational culture has taken different attributes and dimensions. Several authors have defined culture but they place their own set of attributes. This large and varying number of attributes is due to the extremely broad and vague set of factors constituting the organizational culture. Cameron and Quinn (2005) have developed a framework that includes the most important factors that define a culture. The main factors are related to people: how they think, interact, and resolve problems based on their values and assumptions. After several studies, Cameron and Quinn (2005) came up with frameworks that include four clusters: adhocracy, clan, hierarchy, and market. Each one of these clusters defines a cultural type. An adhocracy, in a business context, is a corporate culture based on the ability to adapt quickly to changing conditions. A single visionary usually leads the adhocracy culture without a need for formal policies. The glue that holds the organization together is commitment to experimentation and innovation. Therefore, the challenge is to create something new to maintain the competitive edge. That is why leaders are usually creative, entrepreneurial, and risk oriented. When the company grows, its culture starts to resemble a clan culture. Under the clan culture, the company becomes similar to a family-type organization, where employees share the same values and goals and feel a sense of belonging to the company. The main features of a clan are mainly teamwork, employee involvement, and top management support with a main focus on its people. When the organization grows even more, rules and regulations become a must to control the work environment, making the company resemble a hierarchical culture which is usually characterized by formal structures and procedures. The main purpose of formalizing the cultural structures and procedures is to maintain a stable and predictable output. When personnel shift from a clan to a hierarchal culture, they lose the feeling of belonging to a family and, consequently, their personal satisfaction decreases. As the company gets oriented toward external affairs rather than internal ones, it takes the form of a market culture. The main features of a market culture are competitiveness and productivity with the main goal of generating more money. Under this market, leaders are usually competitors and makers (Cameron and Quinn 2005). 


\section{METHODOLOGY}

The research methodology used in this study is Design Science Research (DSR). DSR offers an alternative approach for understanding, solving practical problems, and evaluating innovative artifacts in construction management as it bridges the gap between theory and practice (Khan \& Tzortzopoulos 2018). Since DSR requires the creation of an innovative artifact relevant for both practitioners and academics, the artifact must be well presented, coherent, and internally consistent (Hevner et al. 2004). The research procedure of this study comprises the following steps. First, a thorough literature review is conducted to understand the organizational culture on the one hand, and derive the features of lean culture on the other hand. Then, a questionnaire is designed according to the derived features. Afterwards, the questionnaire is pilot tested before getting administered through structured face-to-face interviews with employees at several construction companies. The resulting data collected from the questionnaires is then statistically analyzed and discussed. Finally, conclusions and recommendations are put forth towards a better implementation of lean culture within construction firms.

\section{QUESTIONNAIRE DESIGN}

In order to assess the current organizational culture in Lebanon, a questionnaire was prepared to collect the necessary data for this study. The survey is divided into two main parts; the first part comprises questions aimed at gathering general information, and the second part presents questions that help assess the existing culture at Lebanese construction firms. The survey contains 60 statements which participants must rate, on a Likert scale (1 to 5), the extent of which those statements are adopted in their company. The first draft of the survey was pilot tested and then adjusted accordingly. In the general information part, the questions focus on the role of the participant in the company and years of experience, the company's size and its years spent working under lean principles (if applicable). The focus is to differentiate mainly between the responses of white/blue collar employees and between the company size (medium /large). The second part of the questionnaire contains 60 statements. Each statement targets one or more of the 48 features of Lean Culture shown in figure 1 which derived from the thorough review of research on lean and its applications.

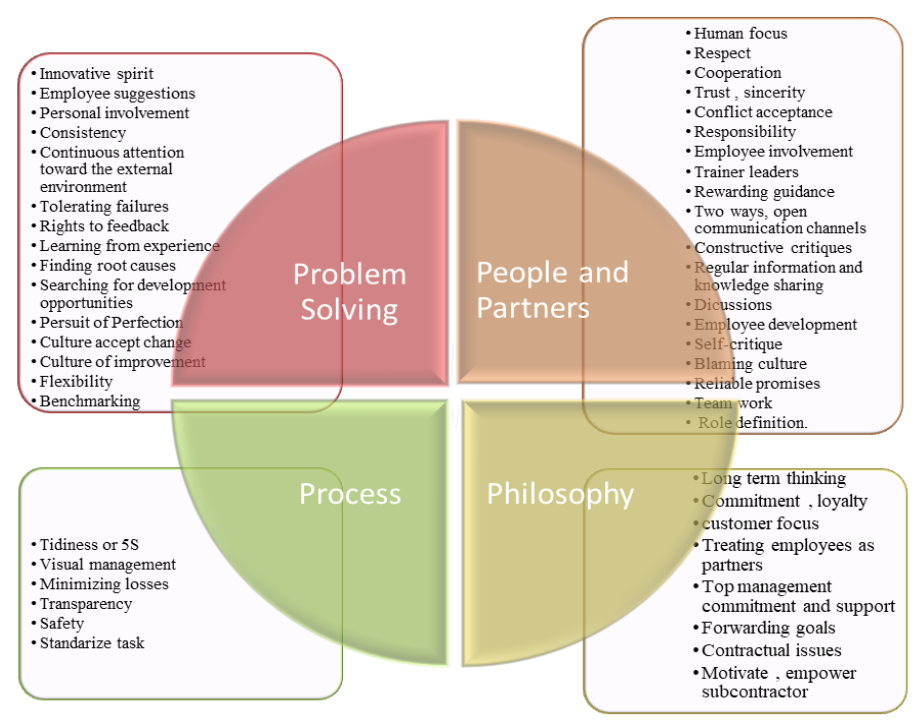

Figure 1: Lean Features according to the 4P model inspired from Liker 2004. 


\section{DATA COLLECTION}

Structured face-to-face interviews were conducted to administer the questionnaires to employees on construction sites. Twenty construction sites representing twenty different companies were visited in different Lebanese districts. The selected companies include 10 large-scale and 10 medium-scale companies. During the interviews, the purpose of the study was first clearly described, and the anonymity of the survey was continuously emphasized on to avoid any hesitancy in responding. Then, all the survey questions and statements were thoroughly explained to the participants, and the questionnaires were administered in the same manner to all participants to avoid biases. On most sites, the questionnaires were administered in groups of four to five white-collar employees. On the other hand, it was hard to group blue-collar employees, so questionnaires were administered individually. The total number of completed surveys was 109 divided into 77 surveys completed by white-collar employees and 32 completed by blue-collars. The difference in the number of completed surveys between the two groups is due to having less foremen (blue-collar employees) on site than the number of engineers (white-collar employees).

\section{DATA ANALYSIS AND DISCUSSION}

\section{Comparing BLue AND White-Collar EMPloyeeS}

The responses given by the blue and white-collar employees that were interviewed were averaged separately. To check for any significant differences between the answers given by the blue- and white-collar employees for each company, the non-parametric MannWhitney U-test was applied. The test results showed a clear difference between the responses of the white- and blue-collar employees. In sixteen out of twenty companies, the blue collars tend to score higher than the white-collar employees. This difference could be attributed to the blue-collar employees tending to overemphasize the lean culture or possibly not trusting that the survey is anonymous.

\section{Assessing the Features of the Lebanese Construction Culture}

Each question in the survey addresses one feature of lean culture as discussed earlier. To assess the current Lebanese construction culture, a box plot was generated for each of the 60 questions. Since the results of the blue-collar employees were inflated and reflected that they overemphasized the lean culture, only the answers given by white collars (77 respondents) were taken into consideration. Additionally, since most of the questions have a median of three, only the questions having high variability, low variability, a median less than three, and a median greater than four were taken into consideration. In order to know which features in the Lebanese construction culture are related to lean culture, the questions that have a median of four and above were considered in addition to those questions having low variability with a median of four. On the other hand, for the purpose of identifying the features that need to be improved for a better implementation of lean construction in Lebanon, questions having a median less than three were considered. Furthermore, questions having large variability were taken into consideration as they reflect the existence or absence of the lean features within the investigated companies. Accordingly, a one-sample sign test was conducted to check if the median values of the questions rank three and above. The p-values and a brief discussion on each question are shown in Table 1. The topic of each question is highlighted in bold in table 1 . 
Table 1: Sign test for specific questions

\begin{tabular}{|c|c|c|c|c|c|}
\hline & $\begin{array}{l}\text { Ques } \\
\text { tions }\end{array}$ & Null Hypothesis & $\begin{array}{l}\text { Sign test } \\
+p \text {-value }\end{array}$ & Decision & Topic Discussion \\
\hline \multirow{6}{*}{ 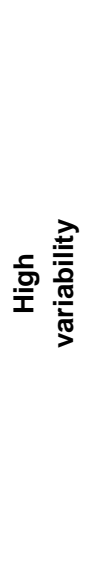 } & Q19 & $\begin{array}{l}\text { Population median of } \\
\text { question } 19=3\end{array}$ & $\begin{array}{c}p \text {-value }= \\
0.410\end{array}$ & $\begin{array}{l}\text { Fail to } \\
\text { reject HO }\end{array}$ & $\begin{array}{l}\text { Employee development: some companies } \\
\text { invest in the development of the employees' } \\
\text { skills }\end{array}$ \\
\hline & Q23 & $\begin{array}{l}\text { Population median of } \\
\text { question } 23=3\end{array}$ & $\begin{array}{c}p \text {-value }= \\
0.2\end{array}$ & $\begin{array}{l}\text { Fail to } \\
\text { reject Ho }\end{array}$ & $\begin{array}{l}\text { Pursuit of perfection: some companies have } \\
\text { annual reviews to measure improvement, } \\
\text { others do not. }\end{array}$ \\
\hline & Q30 & $\begin{array}{l}\text { Population median of } \\
\text { question } 30=3\end{array}$ & $\begin{array}{c}\mathrm{p} \text {-value } \\
0.519\end{array}$ & $\begin{array}{l}\text { Fail to } \\
\text { reject H0 }\end{array}$ & $\begin{array}{l}\text { Benchmarking: some companies benchmark } \\
\text { other top performers }\end{array}$ \\
\hline & Q31 & $\begin{array}{l}\text { Population median of } \\
\quad \text { question } 31=3\end{array}$ & $\begin{array}{c}\mathrm{p} \text {-value }= \\
0.081\end{array}$ & $\begin{array}{l}\text { Fail to } \\
\text { reject HO }\end{array}$ & $\begin{array}{c}\text { Only some companies pay attention to the } \\
\text { external environment }\end{array}$ \\
\hline & Q43 & $\begin{array}{l}\text { Population median of } \\
\text { question } 49=3\end{array}$ & $\underset{1}{p-v a l u e}=$ & $\begin{array}{l}\text { Fail to } \\
\text { reject } \mathrm{HO}\end{array}$ & $\begin{array}{l}\text { Self-critique: not all employees do their own } \\
\text { self-evaluations. }\end{array}$ \\
\hline & Q49 & $\begin{array}{l}\text { Population median of } \\
\text { question } 49=3\end{array}$ & $\begin{array}{l}\mathrm{p} \text {-value }= \\
0.220\end{array}$ & $\begin{array}{l}\text { Fail to } \\
\text { reject } \mathrm{HO}\end{array}$ & $\begin{array}{l}\text { Tolerating failures: some employees try to } \\
\text { hide mistakes instead of fixing them. }\end{array}$ \\
\hline \multirow{3}{*}{ 章 } & Q28 & $\begin{array}{l}\text { Population median of } \\
\text { question } 28<3\end{array}$ & $\begin{array}{l}p \text {-value }= \\
1.957 e-10\end{array}$ & Reject HO & $\begin{array}{l}\text { Flexibility: the company can respond rapidly } \\
\text { to the changes implemented by the owner. }\end{array}$ \\
\hline & Q34 & $\begin{array}{l}\text { Population median of } \\
\text { question } 34<3\end{array}$ & $\begin{array}{l}p \text {-value }= \\
2.135 \mathrm{e}-11\end{array}$ & Reject HO & $\begin{array}{l}\text { Treating employees as partners : people in } \\
\text { the organization take pride in the company's } \\
\text { products and services. }\end{array}$ \\
\hline & Q5 & $\begin{array}{l}\text { Population median of } \\
\text { question } 5<3\end{array}$ & $\underset{1}{p \text {-value }}=$ & $\begin{array}{l}\text { Fail to } \\
\text { reject } \mathrm{HO}\end{array}$ & $\begin{array}{l}\text { Trust: respondents do not trust the promises } \\
\text { made by their subcontractors. }\end{array}$ \\
\hline \multirow{5}{*}{$\begin{array}{l}m \\
v \\
\frac{c}{\pi} \\
\frac{\pi}{\delta} \\
\sum \\
\Sigma\end{array}$} & Q14 & $\begin{array}{l}\text { Population median of } \\
\text { question } 14<3\end{array}$ & $\begin{array}{l}\mathrm{p} \text {-value }= \\
0.997\end{array}$ & $\begin{array}{l}\text { Fail to } \\
\text { reject HO }\end{array}$ & $\begin{array}{l}\text { Training: shows the companies' lack of } \\
\text { training for their employees. }\end{array}$ \\
\hline & Q32 & $\begin{array}{l}\text { Population median of } \\
\text { question } 32<3\end{array}$ & $\begin{array}{c}\mathrm{p} \text {-value }= \\
0.9818\end{array}$ & $\begin{array}{l}\text { Fail to } \\
\text { reject HO }\end{array}$ & $\begin{array}{l}\text { Human focus: respondents agreed that } \\
\text { companies do not value employees. }\end{array}$ \\
\hline & Q48 & $\begin{array}{l}\text { Population median of } \\
\text { question }<3\end{array}$ & $\underset{1}{p \text {-value }}=$ & $\begin{array}{l}\text { Fail to } \\
\text { reject } \mathrm{HO}\end{array}$ & $\begin{array}{l}\text { Blaming culture: respondents agreed that the } \\
\text { culture leans towards blame. }\end{array}$ \\
\hline & Q50 & $\begin{array}{l}\text { Population median of } \\
\text { question } 50<3\end{array}$ & $\begin{array}{c}\mathrm{p} \text {-value }= \\
0.9991\end{array}$ & $\begin{array}{l}\text { Fail to } \\
\text { reject HO }\end{array}$ & $\begin{array}{l}\text { Tolerating failures: respondents agreed that } \\
\text { employees feel that a shortcoming is someone } \\
\text { else's responsibility }\end{array}$ \\
\hline & Q59 & $\begin{array}{l}\text { Population median of } \\
\text { question } 59<3\end{array}$ & $\begin{array}{c}\mathrm{p} \text {-value } \\
1\end{array}$ & $\begin{array}{l}\text { Fail to } \\
\text { reject Ho }\end{array}$ & $\begin{array}{c}\text { Contracts: respondents agreed that contracts } \\
\text { are written in a way that put the parties in } \\
\text { adversarial relationship. }\end{array}$ \\
\hline 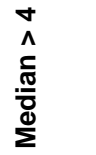 & Q16 & $\begin{array}{l}\text { Population median of } \\
\text { question } 16>4\end{array}$ & $\begin{array}{l}\text { p-value }= \\
5.551 \mathrm{e}-16\end{array}$ & Reject HO & $\begin{array}{l}\text { Consistency: respondents agreed/ strongly } \\
\text { agreed that the company strives to deliver } \\
\text { same/better-quality product. }\end{array}$ \\
\hline
\end{tabular}

\section{EVALUATING THE DIFFERENCE IN 4P'S}

Each question in the survey reflects one of the 4P's of the Toyota Way. 9 questions are related to the Philosophy, 10 questions are related to the Process, 21 questions are related to People and Partners, and 20 questions are related to Problem Solving. A total of 77 averages were calculated for each P. Those averages were statistically analysed to establish if the four Ps are significantly different from each other. The Kruskal-Wallis non-parametric rank sum test was performed, and the test results provided enough evidence to reject that the four Ps are equally ranked. To identify which groups are significantly different from the others, the pair wise Wilcox test with holm as the adjusted p-value was applied. The results showed that Process was significantly higher than Philosophy, People and Partners, and Problem solving with a 90\% confidence interval. 


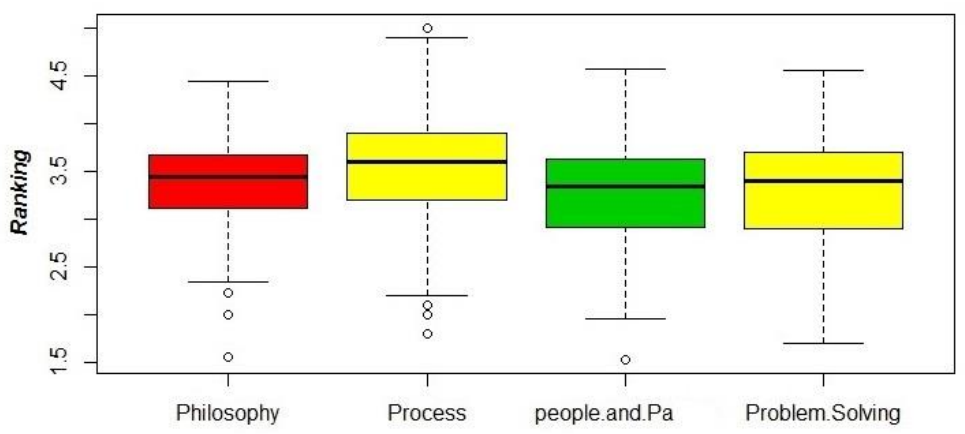

Figure 2: The distribution of the 4P's for white-collar participants

As figure 2 shows, the findings indicate that the interviewed companies tend to focus on the Process more than the other P's because engineers are usually more goal-oriented, believing that they can fix everything related to the process without realizing that the process is founded upon main pillars such as philosophy, people and partners, and problem solving. Liker (2004) states that "it's the people who bring the system to life", reflecting the need for companies to invest in their people by providing employees with the appropriate safe environment not only related to on-site safety, but also where employees feel that they have a secure job. Moreover, companies must value their employees and provide them with a long-term career path alignment along with the necessary training and education. Also, companies must involve employees in decisionmaking, listen to their suggestions, and implement them. Companies should also provide incentives to their employees to enhance the motivation of the employees who will better contribute to the growth of the company. On the other hand, employees, regardless of their role, seniority, and position, must learn to respect and treat each other equally.

Enhancing the Process facet alone is not enough to bring about the desired change; companies need to constantly upgrade their underlying systems for continuous improvement. Therefore, companies should encourage their employees to innovate and find better ways to deliver a product or service. Firms can also enhance their systems by building a culture where employees learn from failure and see the latter as an opportunity to avoid future mistakes as well as progress their experience rather than placing the blame on others. In addition, standardizing the best practices and continuously improving them can reduce wastes resulting from inefficient systems. Similarly, management and employees should accept and implement constructive feedback received internally and externally towards expanding their horizons and continuously improving their system.

At the core of enhancing both the processes and underlying systems is the need for employees to understand the fundamental philosophy behind them. Based on this premise, companies should work on growing and aligning the whole organization towards a common purpose and a shared view of a desired future state. This purpose and common vision should be clearly understood by and shared among all employees of the organization and lived out over a worth-while period of time. These efforts and endeavors carried out by the company should be favored over monetary gains. Moreover, decisions of firms and their derived methods must be based on a long-term philosophy even if it comes at the expense of short-term financial goals. People, regardless of their hierarchical level and role at the firm, should derive satisfaction and a sense of accomplishment from their involvement and participation at work. Finally, companies must respect their partners and aim towards a continued return business with them. 
Although the authors tried to dissect the elements of the 4P's, the elements are highly interrelated. For instance, companies depend on people to reduce waste that results from an inefficient process. Companies also depend on people to identify problems and fix them, which defines the problem-solving process. In fact, none of this can be accomplished without investing in the future of these employees and establishing a shared vision, which embodies the philosophy aspect.

\section{LEAN CULTURE INDEX (LCI)}

This research developed a Lean Culture Index (LCI) to assess the readiness or not of any company to implement lean by understanding its culture. For this reason, the survey was tailored to deduce the LCI. Each question in the survey is related to one feature of lean as discussed earlier. For each white-collar respondent, the results of the 60 questions were averaged. Then for each company, the total averaged answers given by its white-collars were averaged to come up with one value representing the company's LCI. The proposed LCI measures the lean culture and the readiness of a firm to apply lean. An LCI scoring model (Table 2) classifies the lean maturity of construction firms.

Table 1: LCI scoring model for classifying lean maturity within Lebanese construction companies

\begin{tabular}{cllc}
\hline $\begin{array}{c}\text { Average } \\
\text { Score }\end{array}$ & \multicolumn{1}{c}{ Interpretation } & $\begin{array}{c}\text { Large scale } \\
\text { companies }\end{array}$ & $\begin{array}{c}\text { Medium scale } \\
\text { companies }\end{array}$ \\
\hline \multirow{2}{*}{$<180$} & $\begin{array}{l}\text { Companies are not yet ready to implement } \\
\text { lean. }\end{array}$ & N (154.00) \\
& & & $\mathrm{O}(179.50)$ \\
& & $\mathrm{P}(150.33)$ \\
& & $\mathrm{A}(195.75)$ & $\mathrm{S}(178.00)$ \\
$181-210$ & Excessive changes in the company are needed & $\mathrm{C}(198.00)$ & $\mathrm{L}(194.00)$ \\
& before implementing lean & $\mathrm{F}(205.25)$ & $\mathrm{Q}(189.50)$ \\
& & $\mathrm{G}(201.75)$ & $\mathrm{R}(190.50)$ \\
& & $\mathrm{H}(208.75)$ & $\mathrm{T}(203.67)$ \\
$211-240$ & Several improvements in the company are & $\mathrm{J}(196.25)$ & \\
$241-270$ & needed before implementing lean & $\mathrm{I}(235.17)$ & $\mathrm{K}(227.70)$ \\
$271-300$ & Companies are ready to implement lean & - & - \\
\hline
\end{tabular}

As reflected in Table 2, most of the large-scale companies have LCI scores ranging between 181 and 210, so they need excessive system changes before implementing lean. On the other hand, only two companies out of ten need several improvements before implementing lean. For the medium scale companies, most of them scored an average LCI between 181 and 210. Thus, excessive changes in these companies are needed before implementing lean. Furthermore, an alarming $40 \%$ of these companies are not yet ready to implement lean. As a conclusion, the results of the conducted questionnaires in the twenty Lebanese construction firms revealed that most of them need excessive changes before they are ready to successfully implement lean and adopt its culture.

\section{RECOMMENDATIONS}

Based on the outcomes of studying the existing Lebanese construction culture as per the highlighted results in table 1, some culture-related improvements are hereby provided to guide a better implementation of lean construction in Lebanon. First, employees should 
receive the necessary training to foster their skills and lean knowledge even if such training programs are time and cost consuming. In fact, their implementation is crucial for continuous improvement and the long-term benefits can outweigh the initial monetary and time investments. Second, engineers and foremen have doubts in the promises made by subcontractors. Without trust, people cannot exercise reliable promises. Therefore, companies must focus on changing the behavior of people, adopting new ways of thinking, and fostering the relationship with subcontractors before implementing the LC tools. This would also help in gaining competitive advantage in the market place. As a third step, companies must invest in, challenge, and retain productive employees. When employees feel valued and engaged, they are more likely to stay within the organization which, in turn, decreases the firm's turnover rate. Fourth, the most important cultural change is to have a "no blame" culture. This is important when teams are learning from failures. Thus, problems must be seen as learning opportunities to improve conditions instead of placing blames. The project teams must identify the root causes of construction problems and learn from failures to avoid repeating the same mistakes. This will help in reducing of waste and achieving continuous improvement. Fifth, traditional contracts adopted in Lebanon are designed in a manner that puts the involved stakeholders in adversarial relationships. To better apply lean construction, relational contracts should replace the traditional adversarial ones. These types of contracts are based on the relationship of trust between the different involved parties aiming to facilitate the resolution of conflicts (Colledge, 2005). Finally, companies should apply benchmarking strategies to measure the performance of an organization against other similar organizations to achieve higher performance levels. Companies should learn best practices followed by others to introduce breakthrough improvements of their own. Moreover, companies should also be aware of the achievements within their external environment (regional and international companies). This ultimately pushes companies to innovate and continuously improve their systems to maintain their competitive edge within the market.

\section{CONCLUSION}

A Lean Culture Index (LCI) is developed to evaluate the lean culture and the readiness of construction companies to apply Lean. The LCI helped in assessing the lean culture in companies and provided a clearer orientation as to where to look at and what aspects to consider for culture-related improvements. Ultimately, assessing the existing culture of firms and highlighting the drawbacks can help bring the necessary changes to better apply lean construction in Lebanon. To achieve the above, it was important to first derive the features of Lean Culture. A questionnaire was then prepared based on the fifty derived features of Lean. After conducting structured face-to-face interviews with employees of several Lebanese construction firms of different scales, the data was collected and analyzed. Some of the obtained results include the fact that Lebanese construction companies show some relation to lean culture such as flexibility and consistency, but there is still room for improvement in areas such as training, trust, human focus, and type of contracts. Furthermore, the Lebanese culture does not tolerate failures and leans towards a blaming culture. Additionally, companies usually focus on the process more than the other P's of the Toyota Way, since engineers are usually goal oriented and believe that they can fix everything related to the process and operations; however, they fail to realize that behind the process lie the foundation stones of the pyramid: the philosophy, people and partners, and problem solving. Finally, after measuring the LCI, results revealed that most of the large-scale companies need excessive changes in their 
company before implementing LC. Some culture-related improvements were suggested for better implementation of LC in Lebanon. Companies should invest in the development of employee skills and provide trainings. By doing so, the behavior of people would change, and trust would increase. Furthermore, employees must see failures as an opportunity to learn and improve towards reaching a "no blame" culture. Moreover, companies should use benchmarking and learn from the success of others to introduce breakthrough improvements.

\section{REFERENCES}

Bernstein, H. M. \& Jones, S. A. (2013). Lean construction: Leveraging collaboration and advanced practices to increase project efficiency. Intelligence, McGraw Hill Construction, Bedford, MA.

Cameron, K. S. (1997). Techniques for making organizations effective: Some popular approaches. Washington DC: National Research Council.

Cameron, K. S. (2003). Ethics, virtuousness, and constant change. The Ethical Challenge: How to Lead with Unyielding Integrity. Jossey-Bass, San Francisco, CA, 185-194.

Cameron, K. S., \& Quinn, R. E. (2005). Diagnosing and changing organizational culture: Based on the competing values framework. John Wiley \& Sons.

Colledge, B. (2005). Relational contracting: creating value beyond the project. Lean Construction Journal, 2(1), 30-45.

Emiliani, M. L. (1998). Lean behaviors. Management Decision, 36(9) 615-631.

Ettorre, B. (1997), "What's the next business buzzword?", Management Review, 86(8)

Hamzeh, F., Kallassy, J., Lahoud, M., and Azar, R. (2016). "The First Extensive Implementation of Lean and LPS in Lebanon: Results and Reflections." In: Proc. 24th Ann. Conf. of the Int'l. Group for Lean Construction, Boston, MA, USA, pp. 33-42.

Hevner, A. R., March, S. T., Park, J., \& Ram, S. (2004). Design science in information systems research. MIS quarterly, 75-105.

Kenny, M., \& Florida, R. (1993). Beyond Mass Production: The Japanese System and Its Transfer to the US New York: Oxford University.

Khan, S. \& Tzortzopoulos, P. (2018). Using Design Science Research and Action Research to Bridge the Gap Between Theory and Practice in Lean Construction Research. In Proceedings of the 26th Annual Conference of the International Group for Lean Construction, Chennai, India, 209-219.

Kotter, J. P. (1996). Leading Change. New York: Harvard Business School Press. 187.

Liker, J.K. (2004). The Toyota Way- 14 Management Principles from the World's Greatest Manufacturer. New York: McGraw Hill.

Schein, E.H. (2010): Organizational culture and leadership, Jossey-Bass Publishers, San Francisco, 4th ed.

Simonsen, R., Thyssen, M.H. \& Sander, D. (2014), Is Lean Construction Another Fading Management Concept? In Proceedings of the 22nd Annual Conference of the International Group for Lean Construction, Oslo, Norway, 85-96.

Shook, J. (2010). How to Change a Culture: Lessons From NUMMI, MIT Sloan Management Review, 51(2) 63-68.

Wandhal, S. (2014). Lean Construction with or without Lean-Challenges of implementing Lean Construction. In Proceedings of the 22nd Annual Conference of the International Group for Lean Construction, Oslo, Norway, 97-108.

Zammuto, R.F., \& Krakower, J.Y. (1991). Quantitative and Qualitative Studies in Organizational culture. Research in Organizational Change and Development, 5, 83. 